\title{
Placement of a lumen-apposing metal stent for palliation of malignant pyloric stenosis
}

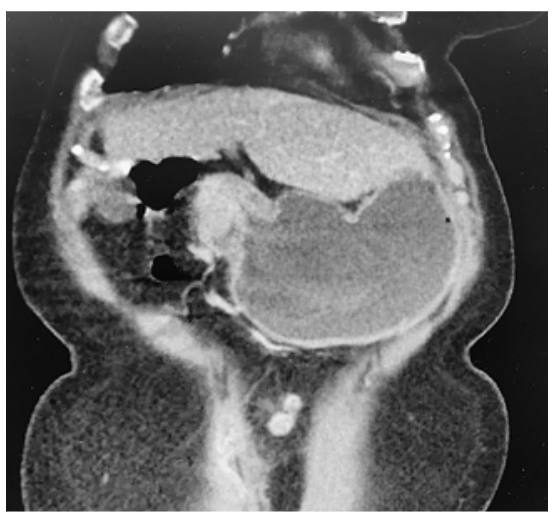

- Fig. 1 Computed tomography scan showing nodular wall thickening of the gastric antrum/first part of the duodenum consistent with serosal metastatic disease causing gastric outlet obstruction.

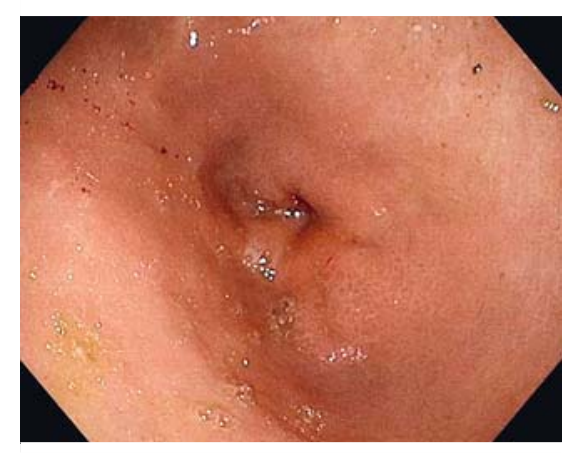

> Fig. 2 Endoscopic view showing pyloric stenosis.

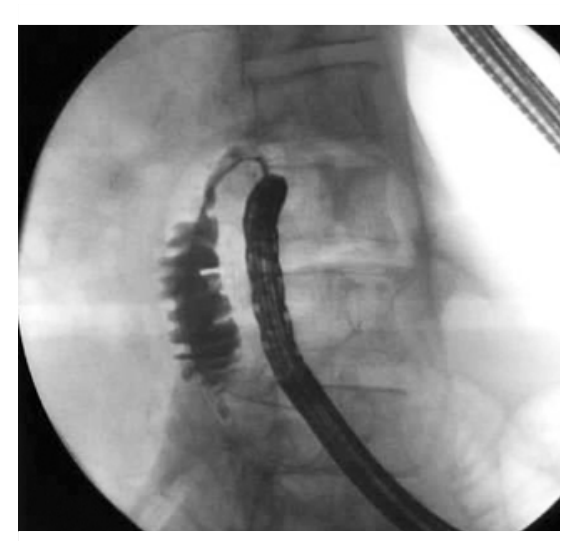

- Fig. 3 Fluoroscopy showing a short pyloric stricture.
A 66-year-old woman with metastatic breast cancer and diffuse osseous disease presented with a history of vomiting after meals for 3 weeks. A computed tomography (CT) scan showed nodular wall thickening of the gastric antrum/first part of the duodenum, which was suspicious for serosal metastatic disease causing gastric outlet obstruction ( $\mathbf{F i g . 1}$ ). An upper gastrointestinal endoscopy was performed for evaluation. A pyloric stricture was visualized (> Fig.2). The stand- ard adult gastroscope could not traverse the lesion; however, a pediatric gastroscope was able to traverse the lesion and showed a short $(<1 \mathrm{~cm})$ pyloric stricture. The mucosa appeared normal, consistent with the CT findings of serosal disease causing the stricture through extrinsic compression. The stricture was also defined under fluoroscopy, which confirmed the endoscopic findings (- Fig.3).

- Fig. 4 Endoscopic views showing: a the proximal end of the lumen-apposing metal stent; b the stent traversing the pyloric stricture.
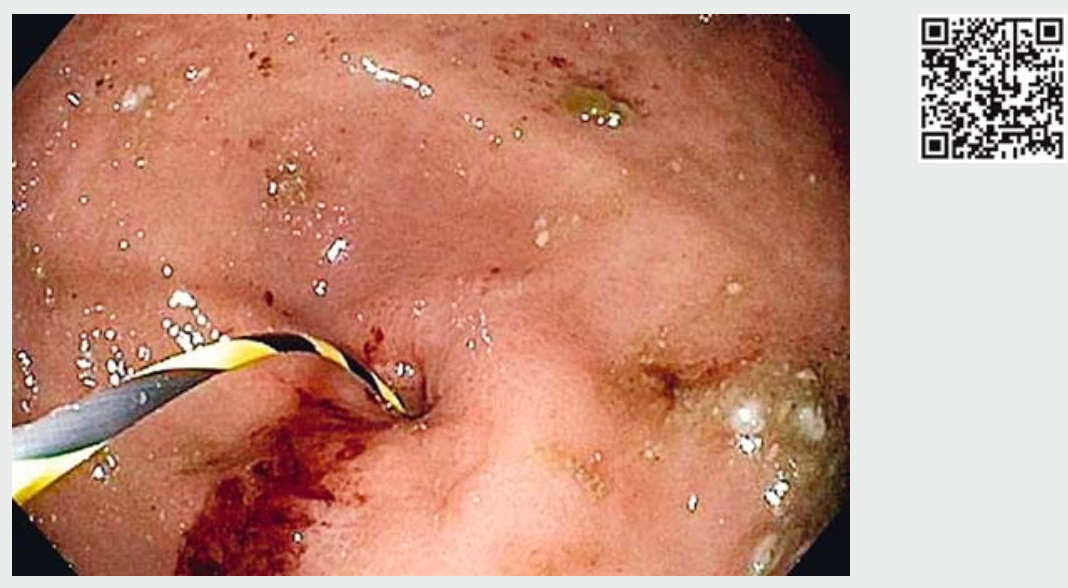

$\checkmark$ Video 1 Placement of a lumen-apposing metal stent for a malignant pyloric stenosis. 
Given the short stricture and possible concerns about migration of a traditional duodenal stent, the decision was made to place a $15 \times 10-\mathrm{mm}$ fully covered lumen-apposing metal stent (LAMS; Axios; Boston Scientific, Natick, Massachusetts. USA). The stent was placed under endoscopic and fluoroscopic guidance ( Fig. 4; $\triangleright$ Video 1 ) using a single-channel therapeutic gastroscope and was successfully deployed. The barbell-shaped LAMS was shown to be straddling the stricture well on endoscopic and fluoroscopic views, which will help prevent migration. After placement of the stent, the patient has had no further symptoms of gastric outlet obstruction and was still tolerating a pureed/soft diet at 4-week follow-up.

To our knowledge, this is the first report of the placement of a LAMS for malignant pyloric stenosis. There are 10 cases in the literature reporting the use of LAMS for benign pyloric stenosis caused by ulcer disease, with variable long-term success [1-3]. We have shown in this case that placement of a LAMS is also a therapeutic option for malignant pyloric stenoses in which the stricture is less than $1 \mathrm{~cm}$.

Endoscopy_UCTN_Code_TTT_1AS_2AG
Competing interests

None

The authors

Arvind J. Trindade, Chun Kit Hung, Howard M. Zimmerman, Petros C. Benias

Zucker School of Medicine at Hofstra/Northwell, Northwell Health System, Division of Gastroenterology, Department of Medicine, Long Island Jewish Medical Center, New Hyde Park, New York, USA

\section{Corresponding author}

\section{Arvind J. Trindade, MD}

Long Island Jewish Medical Center, Zucker School of Medicine at Hofstra/Northwell, 270-05 76th AVE, New Hyde Park, NY 11040, USA

arvind.trindade@gmail.com

\section{References}

[1] Adler DG. Use of a lumen-apposing metal stent to treat pyloric stenosis. Gastrointest Endosc 2017; 86: $742-743$

[2] Irani S, Jalaj S, Ross A et al. Use of a lumenapposing metal stent to treat $\mathrm{Gl}$ strictures (with videos). Gastrointest Endosc 2017; 85: $1285-1289$
[3] Yang D, Nieto JM, Siddiqui A et al. Lumenapposing covered self-expandable metal stents for short benign gastrointestinal strictures: a multicenter study. Endoscopy 2017; 49: 327 - 333

\section{Bibliography}

DOI https://doi.org/10.1055/a-0624-1140

Published online: 12.6.2018

Endoscopy 2018; 50: E210-E211

(c) Georg Thieme Verlag KG

Stuttgart · New York

ISSN 0013-726X

\section{ENDOSCOPY E-VIDEOS}

https://eref.thieme.de/e-videos

回回 Endoscopy E-Videos is a free access online section, reporting 回制: on interesting cases and new techniques in gastroenterological endoscopy. All papers include a high quality video and all contributions are freely accessible online.

This section has its own submission website at https://mc.manuscriptcentral.com/e-videos 